\title{
THE ACTIVE WHEELS SYSTEMS
}

The article discusses active wheel systems used in motor vehicles and aviation. The use of chassis with active wheels, i.e. wheels equipped with integral electric drive, significantly facilitates maneuvering of helicopters during taxiing. This allows you to reduce fuel costs and increase the safety of both helicopter crews and ground personnel.

\section{INTRODUCTION}

Rising fuel prices and the search for the greatest possible savings resulting in new vehicles riding, sailing and flying the use of new structural solutions that can significantly affect fuel consumption, reduced weight, increased motor efficiency. The companies are trying to revolutionize their structures to become more competitive in the market and reduce operating costs and emissions of harmful particles to a minimum. As a result, a potential customer is willing to pay more for a modern solution, because he knows that at a later time gain on the operation of the machine.

In recent times, we see a very large development of alternative energy sources for vehicles of all types. The increasing use of vehicles have a "hybrid"

Hybrid - a combination in one machine (the system interacts) solutions ostensibly taking no interplay. Most often it is a combination of several devices used to be manufactured separately in one and use the advantages of each of these devices.

In recent times, we see the development of very powerful cars with hybrid drive.

The hybrid drive is the most common combination of combustion engine and electric. These motors can operate alternately or simultaneously, depending on the needs, e.g., in .: electrical combustion of town. The electric motor can be a generator and charge the battery or capacitor as a result of driving an internal combustion engine or as a result of engine braking. Such systems mounted engine has enough power to run at optimum operating parameters at the expected travel speed. It is about a quarter of the power of engines currently in use. The whole is controlled by an electronic system to ensure optimum use of energy.

A helicopter is a type of rotorcraft in which lift and thrust are supplied by rotors. This allows the helicopter to take off and land vertically, to hover, and to fly forward, backward, and laterally. These attributes allow helicopters to be used in congested or isolated areas where fixed-wing aircraft and many forms of VTOL (vertical takeoff and landing) aircraft cannot perform.

\section{EXISTING SYSTEMS OF ACTIVE WHEEL DRIVE}

\subsection{EGTS TM system}

EGTS - system (Electric Green taxi system). EGTS system allows fully automatic way by plane taxied to a designated lane without the need for aircraft engines. The two main wheels are equipped with an electric motor, matched unique power and system controllers give pilots total control over the speed and direction of the aircraft during taxiing operations. The innovative system has been developed by Honeywell and Safran Groupe. EGTS is equipped with an engine of $50 \mathrm{~kW}$, which directly drives the wheels of the aircraft. It is a very simple idea, but the same execution is more complicated. Progress in this industry exists because of the development of electric motors which are smaller lighter and more efficient. The engine is built directly into the wheel plane (main landing gear), powered by the APU (Accelerated Processing Unit) and controlled by pilots using a simple joystick. The system will be designed to accelerate the aircraft to a speed of about $40 \mathrm{~km} / \mathrm{h}$. It will be fully prepared to serv inclined roads and ramps. The idea is to work in all weather conditions

This system is a response to the needs arising from the airline cost and environmental initiatives working in high positions airline companies. EGTS provides an effective solution to achieve lower cost of ownership of aircraft, and reduce emissions into the atmosphere will burn. This innovative system allows airlines to save several hundred thousand dollars a year, and at the same time improve profits. On a global scale, this mechanism could yield more than $4 \%$ of the total fuel which is more than 5 million tons of fuel per year. What gives more than 250 per thousand \$ savings per aircraft per year. EGTS system is more environmentally friendly, with proper design it is possible to reduce by $75 \%$ carbon dioxide and $50 \%$ reduction of NOx only during taxiing operations. Added value is that the system completely eliminates the need for tow vehicles terrestrially to the apron or the gates of increasing safety for ground handling. A further advantage is to increase the service life of aircraft engines and reduce noise at the airport.

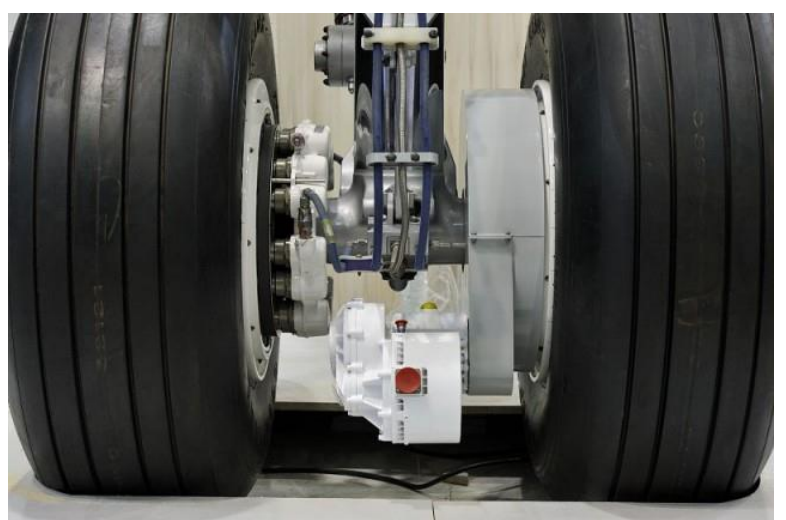

Fig. 3. The EGTS $50 \mathrm{kw}$ motor and drive system on the $A 320$ main gear. It's the white and grey unit. [3]

\subsection{Michelin}

The Michelin consists of two mechanisms inside the wheel, one of which is responsible for driving and braking, and the other is responsible for active energy control of the suspension. All other components of transmission, transmission are integrated inside the 
circle. According to the objectives of the system it is to weigh about $42 \mathrm{~kg}$, and comprising a small water-cooled drive motor. Intelligent wheel to navigate the vehicle through electricity (thanks to a miniaturized electric motor), while providing the functions of depreciation and braking. The system consists of a tire, the electric drive, the active suspension and friction brakes. This arrangement allows to free the vehicle from the engine and the transmission and thus get more space. 'Each wheel is equipped with an independent system which allows mounting of two drive wheels (Active Wheel system on each of the front wheels and two identical systems for the rear wheels, but without engines) or the four-wheel drive (Active Wheel one for each wheel). One pair of wheels Active Wheels produces 60 $\mathrm{kW}$, or approx. 40 horsepower.

With this solution, Michelin intends to invent the wheel again and propose a coherent system in which the running gear, drive and tires are designed for close cooperation in order to better exploit the chassis than traditional solutions. The sound of the 2 small electric motors much like passing metro and despite the small announced power should appreciate the liveliness of the drive and excellent reactivity, a characteristic of electric vehicles. Through this project, Michelin has proved a high degree of technological sophistication of its solution, which may become part of future cars.

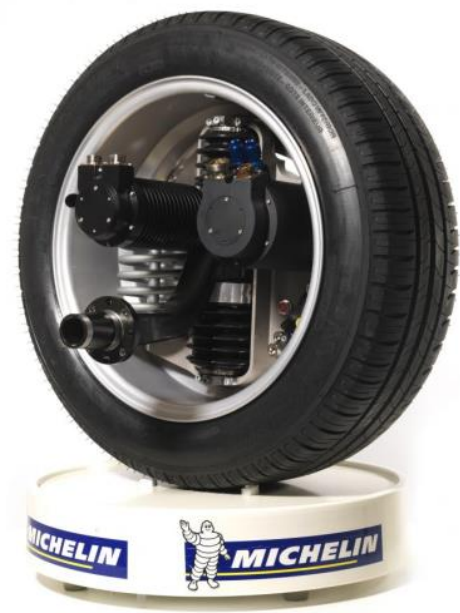

Fig. 4. Active wheel design by Michelin [4]

Michelin did not find in the market any power source for Active Wheels, which correspond to the assumptions of the design, which is why he undertook the develop an advanced technology fuel cell. This system is characterized by weight halved the available solutions on the market while increasing autonomy, allowing Traversing up to 200 kilometers.

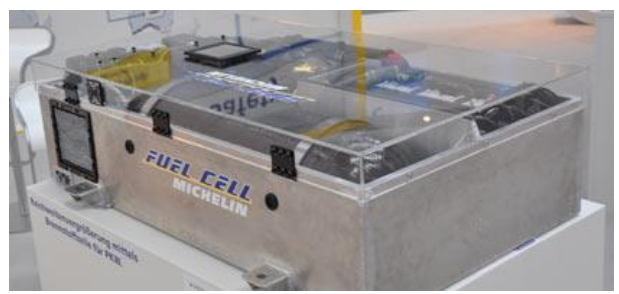

Fig. 5. Fuel Cell Michelin [4]

This product was developed based on the car F-City $\mathrm{H} 2$, designed for city driving. In France, it is a vehicle of historical importance as the first hydrogen car registered in that country. There remains only the problem of charging, because in contrast to Germany, France can't boast a large number of hydrogen fuel stations.

\subsection{Protean Electric's}

Protean system-is a completely new concept for a solution of the active wheel. Structural engineering team created a permanent magnet and a conventional motor inside and outside the rotors is directly screwed to the traditional road wheel. Micro inverter control electronics and software are integrated within each of the motor on the inside of the stator. Permanent magnet motor mounted on a periphery of the rotor in order to maximize the torque. As a result, the electric motor is Protean maximum torque of the main motor in the industry. At $80 \mathrm{~kW}$ and maximum torque of $800 \mathrm{~nm}$, each engine weighs only $31 \mathrm{~kg}$ and is chosen so that it fits in the space of a conventional running wheel with a diameter of 18 inches. Protean system can reduce fuel consumption by more than 30 percent, but this depends largely on the size of the battery and driving characteristics. The engines are powerful enough to be the only source of drive, and can also be easily adaptable to hybrid cars in a wide range.

The electric power mounted within the engine is divided into the so-called. "Under-engine" to improve loading, heat dissipation and safety. The control system can enable or disable the "under-engine" (as happens in the engine cylinders) for the system to work with maximum efficiency in the full range of work. The problem I had to overcome the engineers to increase the unsprung masses. In conducting research using new engineering development drive which aimed to optimize the elements of suspension springs and damping. Engineers that the wheels included in the circle gives significant advantages in torque, additional handling, security and control. Two motors in the wheels of Protean can provide a moving vehicle in the urban cycle, ensuring zero emissions by switching off the petrol engine. Motors of this type have microassemblies electronic inverter with integrated software control.

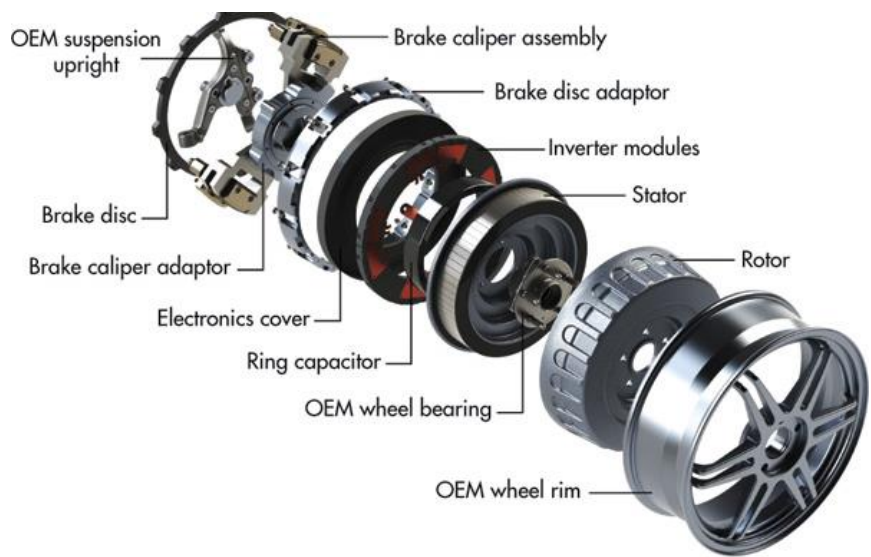

Fig. 1. Custom micro-inverter from TT electronics will provide the integrated power electronics in Protean in-wheel electric drive system [5].

\subsection{Ellica}

Ellica based on a high-speed drive consisting of motor and gearbox. In order to create proper cooperation with the drive motor is required to accurately determine the transmission. The most suitable is a planetary gear due to low weight $(0.2 \div 1 \mathrm{~kg} / \mathrm{kW})$ and a small ratio $(3 \div 35)$. Such mechanisms must be cooling water, assuming the assumptions that the coolant temperature is $65^{\circ} \mathrm{C}$ and the convection coefficient between the electric motor and the coolant should be $6000 \mathrm{~W} / \mathrm{m} 2 \mathrm{~K}$. Establishment of the car Ellice developed at Keio University in Japan is based on a maximum of 8 engines, each with a capacity of $60 \mathrm{~kW}$.

Professor Shimizu who developed the concept car Ellice in their work introduced variants in which the car can be implemented. The 
Sim Drive can be offered in 2WD configuration, 4 WD, WD 8. The whole structure is based on the principle of skateboards. The whole mechanism is based on the floor frame on which are mounted the drive mechanisms for braking and suspension. It is an independent system which is mounted on the shell structure of the vehicle. The car of this type developed during testing speed of $310 \mathrm{~km} / \mathrm{h}$. The premise of destination, however, is that the car was used for small urban vehicles.

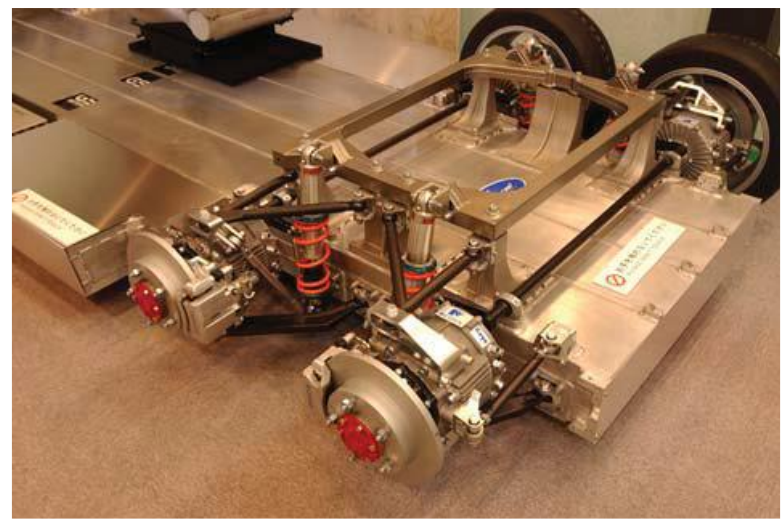

Fig. 7. High-speed motors arranged in the Japanese car test Ellica [6]

\subsection{Honda}

Honda began work on a low speed engines, the system consists of installing the drive motor to the wheel disc. Compared to the engine high-speed, low-speed motor has a rated torque value greater by an order of magnitude. The engine works in the construction of convention reverse. The armature is stationary and the rotor magnets are disposed. The rotor is a disc wheel. Armature takes the shape of a toroidal, and this allows for the development of space inside, which makes it possible to place there the brake or suspension parts. The direct drive low speed of cooling is also necessary. It is a forced circulation. The cooling agent may be air or liquid. Is required coolant temperature $35^{\circ} \mathrm{C}$ and the convection coefficient between the electric motor and the cooling medium should be 190 $\mathrm{W} / \mathrm{m} 2 \mathrm{~K}$. Very interesting to compare the direct-drive and diesel drive with comparable mechanical properties. These measurements made an Institute of Electrical Drives (EAA) at the Federal University Protection in Munich. The graph shows the comparative measurements of the characteristics of torque for direct drive low speed and drive a classic drive combustion. We compared the characteristics of the car until the average size of the mounted electric power of $45 \mathrm{~kW}$ (motors placed in the 4 wheels) and total torque of $1800 \mathrm{Nm}$. These parameters are sufficient to compare the torque characteristics at low speeds. Combustion engine had a maximum torque of $300 \mathrm{~nm}$, gears first gear 12.74 , transmission efficiency of $95 \%$ and drives are only two wheels.

Drive the vehicle as a prototype Honda FCX Concept (formerly FCV- Fuel cell vehicles) consists of installing three energy-efficient motors driving four wheels. It is a hybrid. On the front is placed internal combustion engine with a capacity of $80 \mathrm{~kW}$ drives the front wheels and two electric motors in the rear wheels with a capacity of $25 \mathrm{~kW}$ each. These engines are powered by energy from the fuel cells. The vehicle has a spacious interior and cabin for passengers. Marks a new stage in the evolution of fuel cell technology.

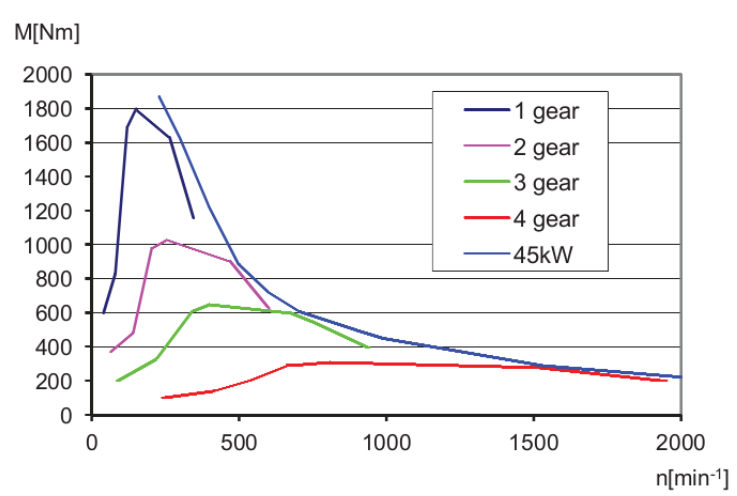

Figure 8. Comparison of torque characteristics depending on the speed for a medium size car with a combustion engine and electric motors with low speed direct arranged in four wheels [7]

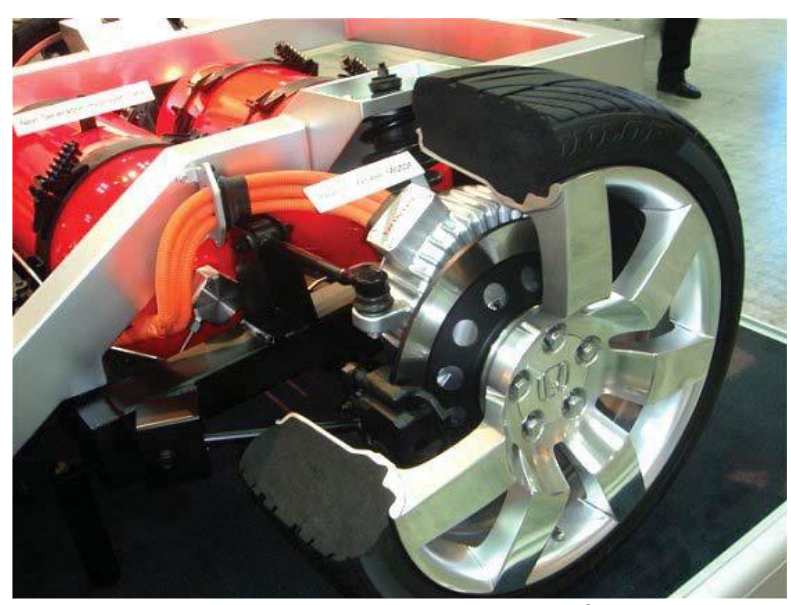

Fig. 9. Direct drive system designed by Honda [8]

\subsection{VDO Siemens}

Siemens same as the Honda engine is a low speed. He leads the research on direct drive equipped with an armature in the form of toroidal. This makes it possible ary placed in the inner space of additional components, such as active suspension and brake wedge. The VDO under the name ECorner. This concept is the basis for operating wireless devices while driving a car, which will be gradually introduced in the coming years. This is one of the first design prototype having control modules ECM.

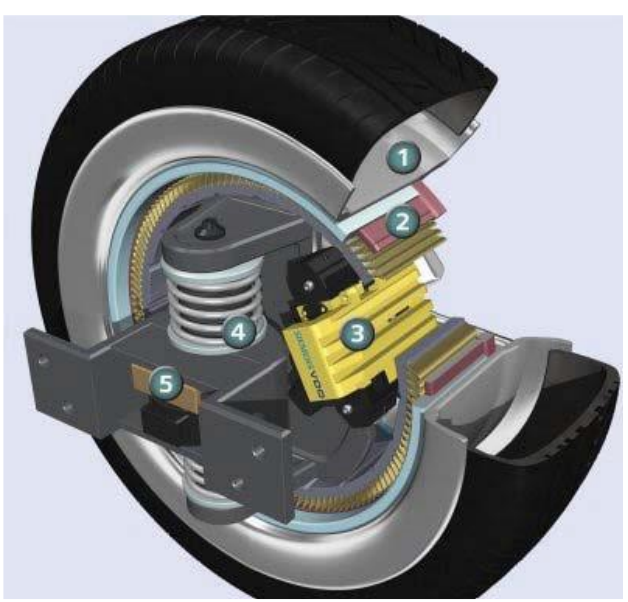

Fig. 10. System FOR Siemens: 1 - wheel disc 2 - rotor engine, 3 electronic wedge brake, 4 - active suspension, 5 - electronic controller [9] 


\subsection{IMIEV Mitsubishi Motors Corporation}

Motor armature which offer Mitsubishi company also is donutshaped. Just as in the previous two examples, it is a mechanism for low speed. It has a toroidal structure that allows placement of the brake mechanism and other elements in the central portion of the engine. This eliminates the difficulties associated with the steering, allowing the installation of engines as the front wheels

\subsection{Volvo ReCharge}

An electric motor at each wheel The Volvo ReCharge Concept combines a number of the latest technological innovations into a socalled "serial hybrid system" (series hybrid), where there is no mechanical connection between the engine and the wheels. The batteries located in the boot are made in the technology of lithiumpolymer battery. The service life of the battery is longer than the car. Four electric motors, one at each wheel, provide an independent drive. The four-cylinder Flexifuel engine with a capacity of 1.6 liters drives an advanced generator that efficiently powers the wheel motors when the battery is depleted. An electric car with a backup combustion engine Volvo ReCharge Concept is a battery electric car, equipped with an efficient generator, so-called. auxiliary energy unit (APU), that steps in when the battery charge becomes insufficient for adequate driving performance. The APU is designed to supply electrical power to the individual motors at each wheel. Since the combustion engine only powers the APU, it can operate in an optimal fashion, both for regulated emissions and $\mathrm{CO} 2$. The APU is sufficiently powerful to supply an entire villa with electricity. Theoretically, the owner of the car equipped unit has at its disposal its own power generator in case of power failure. The driver selects the power source The combustion engine starts up automatically when 70 percent of the battery power. However, the driver can also manually start the four-cylinder Flexifuel engine via a button on the dashboard. This allows the driver to start the engine earlier in order to maximize battery charge, for instance when out on the highway in order to save battery capacity for driving through the next town. Specially designed electric motors Basic electrical units Volvo ReCharge Concept demonstrator, the generator for the APU and the wheel motors have been developed in cooperation with the British company PML Flightlink specializing in electromagnetic technologies. With an individual electric motor at each wheel, weight distribution as well as mechanical efficiency and traction. The friction in mechanical gears. Since the car does not have the transmission found in ordinary cars, does not have a gear lever. To maximize the environmental benefits, the Volvo ReCharge Concept is equipped with tires with low rolling resistance, developed by Michelin. They were designed specifically for this vehicle. In addition, the car has All Wheel Drive in the truest sense of the word - each wheel is controlled individually. The energy generated during braking is transmitted to the battery. In the final version of the traditional wheel brakes will be replaced electrical brakes. To ensure the reliability of the drive system and braking system, driver inputs are fed into quadruple-redundant electronic control system.

\section{CONCLUSIONS}

After analyzing the literature you will see that problem "active wheel" in browns automotive and aviation industry is constantly analyzed and developed. Every moment there will be new solutions to the problem.

\section{BIBLIOGRAPHY}

1. Rotary Action, http://www.rotaryaction.com/history.html, Rotary Action. [Online].

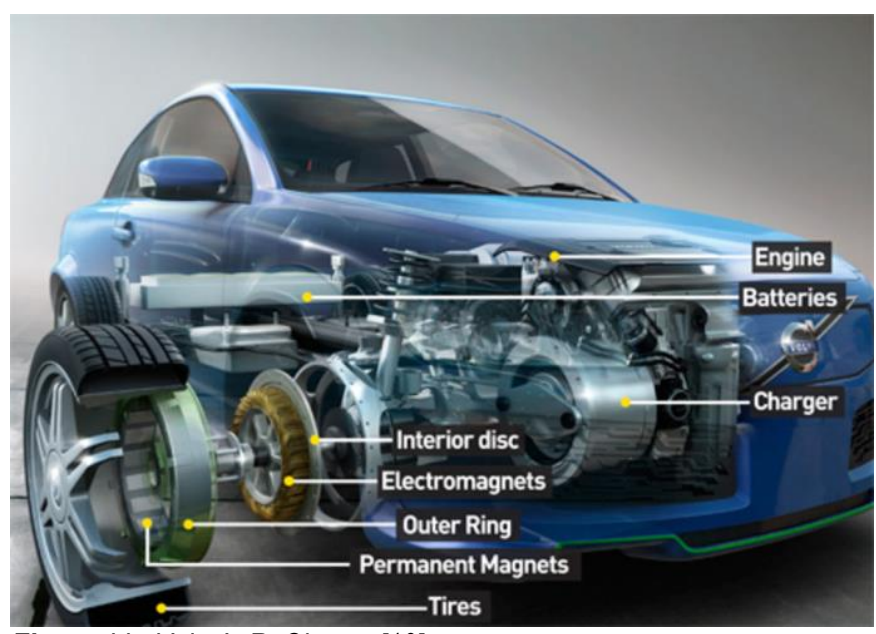

Figure 11. Volvo's ReCharge [10]

2. DARPA, http://www.darpa.mil/news-events/2015-09-10, Defense Advanced Research Projects Agency, 2015. [Online].

3. SAFRAN, http://www.safranmbd.com/egtstm, Messier-BugattiDowty Safran Landing Systems. [Online].

4. Michelin, http://www.rezulteo-opony.pl/srodowisko/system-acti-vewheels-oraz-ogniwo-paliwowe-2246, Michelin, 2012. [Online].

5. Protean electric, http://www.proteanelectric.com/, [Online].

6. Eliica EV Fast, http://wardsauto.com/news-analysis/eliica-ev-fasteconomical-and-drawing-interest-japan-s-oes, Eliica EV Fast. [Online].

7. Gerling D., Dajaku G., Lange B., tp://www.proteanelectric.com/ wpcontent/uploads/- /2011/12/protean-Services2.pdf, Electric Traction for Automobiles Compoarison of Differt Wheel Hub Drives. Protean electric, 2012. [Online].

8. Greencar. Could In-Wheel Motors be the Next Big Hing, http://www.greencar.com/articles/-could-wheel-motors-next-bigthing.php, 2012. [Online].

9. G. Hankon M., Siemens VDO visualizes the electric wheel hub motor, http://www.gizmag.com/go/5996/, 07092012.

10. S. Fletcher, http://www.popsci.com/cars/article/2008-03/how-itworks-tomorrows-hybrid, Popular Science, 2008. [Online].

\section{Systemy kół aktywnych}

W artykule omówione zostały systemy aktywnych kót stosowane $w$ pojazdach samochodowych oraz $w$ lotnictwie. Zastosowanie podwozia z aktywnymi, tzn. kołami wyposażonymi $w$ integralny napęd elektryczny, znaczaco ułatwia manewrowanie śmigłowcami podczas kołowania. Pozwala to na obniżenie kosztów paliwowych $i$ zwiększenie bezpieczeństwa zarówno załóg śmigłowców jak i personelu naziemnego.

\section{Autorzy:}

dr hab. inż. Wojciech Żurowski - Uniwersytet Technologiczno-Humanistyczny im. Kazimierza Pułaskiego w Radomiu, Wydział Mechaniczny; 26-600 Radom; ul. Stasieckiego 54. wzurow@uthrad.pl

mgr inż. Mateusz Sadowski - Uniwersytet TechnologicznoHumanistyczny im. Kazimierza Pułaskiego w Radomiu, Wydział Mechaniczny.

mgr Aldona Krzos-Kaczor - Uniwersytet TechnologicznoHumanistyczny im. Kazimierza Pułaskiego w Radomiu. Studium Języków Obcych.

JEL: L62 DOI: 10.24136/atest.2018.216

Data zgłoszenia: 2018.05.28 Data akceptacji: 2018.06.15 